\title{
CORRESPONDENCE
}

\section{Iraq's efforts to reverse the brain drain}

SIR, - I was very pleased with Ziauddin Sardar's article in Nature (January 24, page 327 ) in which the author goes into depth in an effort to describe the exporter and importer countries of scientists and the problems these scientists face in the host countries. Although the report reflects the realities in these countries, it failed to mention anything about Iraq, a country that has a very clear policy in attracting expatriate scientists to return and establish residence in Iraq. In fact as early as 1974, the Revolutionary Command Council of Iraq instituted the "law of return" to any Arab scientist, engineer or holder of a high university degree to return to Iraq. The government, on its part, provided the returning scientists with several enticements including:

all the facilities needed to do science - an option to acquire the Iraqi citizenship after a year's stay

- a lot of land to build a house

a substantial, long term, interest-free loan to effect the building of the dwelling.

Iraq's ambitions to foster science and technology is evident by the construction of new universities and science centres, in recent years, to accommodate the returning scientists as well as to accommodate the ever-increasing number of graduates sent to various developing countries for higher studies and training.

The development of science and technology receives support at the highest levels. Indeed Mr Saddam Hussain, the President of Iraq, gave his clear instructions to do what it takes to develop the scientific base in Iraq. He personally authorised the establishment of a new programme of short-term training seminars to be held in Iraq at government expense. The trainees are Iraqi and other Arab nationals and the training staff are scientists residing in the western world. I personally, along with my colleagues of the Arab American University Graduates (AAUG) had the opportunity to conduct some of these seminars in Baghdad, under the auspices of the Ministry of Health.

Because of its pan Arab nationalistic policy, the government of Iraq insists that "Iraq is for Arabs". This policy is translated into action by waiving the visa requirements to any Arab national, wherever he lives, and who wishes to visit, work or establish a home in Iraq. To my knowledge this is the only Arab country that has felt secure and abolished the visa requirements. To further promote the feeling that Iraq is for Arabs, the non-Iraqi Arab nationals are treated as equal to their Iraqi counterparts. The treatment of "second class citizens" of the expatriates mentioned in Sardar's article is non-existent in Iraq. One can safely deduct that Iraq's long-term ambitions are to bring Baghdad to its golden days as a centre of science and technology.

I am neither an Iraqi national nor a member of the ruling political party, but a concerned Arab scientist residing in the United States and currently on short leave in Switzerland.

AbDallah M. IsA Institut für Klinische Immunologie, Bern, Switzerland

\section{Defending democracy or something else?}

SIR, - Your correspondent (Rolf Seifert, 31 January, page 426) alludes to the "suicide of democracy" if "disruptive Marxists" are allowed to occupy "influential positions" in society. According to cases we are actually involved with, "influential positions" include postmen, railwaymen, teachers of educationally subnormal children and civilian army cooks as well as the cases quoted in Nature (6 December, page 549).

It is the suicide of democracy for the state to monitor legal involvement in the democratic process, to label them arbitrarily as 'disruptive', and then continue to use them as a criteria for the dismissal of long-standing public employees from their jobs. When you defend democracy by such methods, you do not defend democracy, you defend something else.

There is an old English proverb about killing the goose that lays the golden eggs.

C. N. M. POUNDER National Campaign against the Berufsverbote, Edinburgh, UK

\section{Nuclear safety conference open to the press}

SIR, - In "News in Brief"' (24 January, page 326) you mention the IAEA's International Conference on Current Nuclear Power Plant Safety Issues, to be held in Stockholm from 20-24 October 1980, with a misleading title. I would like to make the following points:

- This conference, like all others organised by the Agency, is open to the press and to the public, accommodation in the conference hall permitting.

- The requirement that papers be submitted by governmental designees is a standard requirement for all meetings of the United Nations and its agencies, since they are intergovernmental bodies, and in practice,

therefore, these papers represent a wide range of opinions.

Georges Delcoigne

International Atomic Energy Agency, Vienna, Austria

\section{Makerere University library appeal}

SIR, - We would like to bring attention to some of the difficulties currently being faced by Makerere University in Uganda, particularly with regard to the university's library. All finance for the library was cut off in 1974, and in the last few months since the liberation only a portion of it has been restored. In consequence all runs of the 2000 or so learned journals which the library used to take ceased, as did the purchase of new books. Moreover during the recent fighting many books and much library equipment were looted.

A university cannot function effectively without a good up-to-date library, and teaching and research must both be severely hampered. Makerere used to have one of the best libraries in East Africa, housed in a beautiful building, and both of us have in the past spent many peaceful hours working in it. We have therefore decided to open a fund to help re-equip the library, and we appeal to all those with an interest in Makerere and a concern for education in Africa to contribute generously. We will ensure that the fund is used for the designated purpose by consulting with the librarian and then purchasing and despatching books to him. If you would like to help please send a cheque made payable to the "Makerere Library Fund" to one of us at the address below.

The Queens College, Oxford, UK

Patrick Mangheni

Peter Miller

\section{Maoist dogma clashes with fair appraisal of science}

SIR, - I deplore the descent of Nature into the murky realms of propaganda. A series of feature articles on Chinese science by Tong B. Tang published in the 31 January, 7 February and 14 February issues use the most blatant political jargon, something totally unsuited to a scientific periodical. The epithet ' $\mathrm{Gang}$ of Four', a political insult which would not be out of place of George Orwell's book 1984, 'revisionism', 'capitalist roaders' and other jargon, combined with Maoist unintelligibles like "one divides into two" combine to make the articles unpalatable. Surely the peculiar outpourings of Maoist dogma clash with a fair and dispassionate appraisal of progress in Chinese science. The 'ascent of deviationists' may be of interest to the changing policies of Marxist doctrinal quibblers, but such extravagant phraseology masks what is really the issue - the use of science for political ends. Like so-called Islamic science or even Christian science, these 'sciences' which are oriented to some prearranged goal like the 'dialectics of nature' serve only to bolster the preconceptions and prejudices of dogmatic plutocrats.

Cambridge, UK

Nigel Pennick

\section{Critic of "The Sirius Mystery",}

SIR, - Robert K. G. Temple's long letter (17 January, page 242) seems to have been, in part, motivated by a sense of indignation at not having been appropriately cited by RowanRobinson (in his review of Carl Sagan's "Broca's Brain", (8 November, page 176) nor by Carl Sagan (in his book "Broca's Brain").

It is therefore worth pointing out that Temple himself carefully avoids any reference to articles critical of the claims he makes in his book "The Sirius Mystery." One such article that readers of Nature might wish to know about is Pesch, P. and Pesch, R. The Observatory, 97, 26; 1977.

Warner and Swasey Observatory, East Peter Pesch Cleveland, Ohio, US

\section{Radical test}

SIR, - With reference to the Shirley Williams interview (3 January, page 8), it is odd she should choose herself as "litmus paper" while her colleague, Mr Prentice, so readily changed from red to blue. It seems he failed the acid test of being a radical. 